\title{
DETECTION OF STEM CELLS IN DENTAL FOLLICLE AND BENIGN ODONTOGENIC LESIONS BY IMMUNOHISTOCHEMICAL EXPRESSION OF CD44 AND C-MYC
}

\author{
Hanan Eid Gamal ${ }^{*}$, Abdullah Atef Hammuda** and Saher Sayed Mohammed ${ }^{* * *}$
}

\begin{abstract}
The pathogenesis of odontogenic lesions could be explained by the presence of stem cells as those odontogenic lesions contain a small number of stem cells. Many odontogenic tumors have been reported to originate from stem cells that present in remnants of the dental lamina. The maintenance of stem cells in early dental development is regulated by variety of transcription factors such as OCT-4, SOX-2, CD44, Nanog, Stat-3 and c-Myc. The aim of this study is to evaluate and compare the immunoexpression of two stem cell markers, which are CD44 and c Myc, in dental follicles and in benign epithelial odontogenic lesions. The study included 8 specimens of dental follicle, 6 specimens of inflammatory cysts, 8 specimens of odontogenic keratocyst and 8 specimens of dentigerous cysts. All cases of dental follicles showed positive immunoreaction for the two markers. Regarding c Myc all cases showed +ve immunoreaction except (OKC) were -ve. Regarding CD44 all cases showed +ve immunoreaction. Results of the present study characterize the presence of stem cells in dental follicle and in benign odontogenic lesions illustrating their role in the pathogenesis of these odontogenic lesions.
\end{abstract}

KEYWORDS: Odontogenic lesions, Dental follicle, Stem cells, CD44, c Myc

\section{INTRODUCTION}

Among the most commonly encountered pathological lesions in the head and neck region are the odontogenic lesions ${ }^{[1]}$. Although the etiology of the odontogenic lesions is unknown, there is a strong correlation between them and the development of the dental organs ${ }^{[2]}$. So, the recognition of the differentiation stage of odontogenic epithelial cells is very important, and also the role of these cells in the pathogenesis and the progression of the odontogenic lesions ${ }^{[3]}$.

The pathogenesis of these odontogenic lesions could be explained by the presence of stem cells as those odontogenic lesions contain a small number of stem cells. Many odontogenic tumors have been reported to originate from stem cells that present in remnants of the dental lamina ${ }^{[1]}$.

\footnotetext{
*Lecturer of Oral and Maxillofacial Pathology Faculty of Dentistry Minia University

**Assistant Professor of Oral and Maxillofacial Surgery Faculty of Dentistry Suez University

*** Lecturer of Oral Biology Faculty of Dentistry Minia University
} 
Stem cells are unspecialized cells that can selfrenew, differentiate and, initiate clonal tumor ${ }^{[4]}$. These cells were found to be present in the dental follicle of human wisdom teeth ${ }^{[5]}$. Progenitor cells have been isolated from human dental follicles of impacted third molars using explant cultures or enzymatic digestion of dental follicle tissue ${ }^{[6]}$.

The dental follicle originates from the odontogenic ectomesenchyme. It is considered as a part of the tooth germ which is involved in the formation of cementum, periodontal ligament, and alveolar bone ${ }^{[7]}$. It surrounds the crown of an erupting tooth and is responsible for organization of tooth eruption. It is lined by reduced enamel epithelium of enamel organ that can give rise to some odontogenic cysts and tumors including dentigerous cysts ${ }^{[8]}$. Dental follicles that have reduced enamel epithelium can proliferate into stratified squamous epithelium resulting in dental cysts ${ }^{[9]}$.

Several studies discussed the predominance of various cyst and tumor development related to the asymptomatic follicle of impacted tooth. The follicle may show different histopathological changes during tooth development leading to the development of odontogenic tumors or cysts ${ }^{[7]}$.

Tumor stem cells (TSCs) are believed to produce benign and malignant tumors ${ }^{[10,11]}$. The maintenance of stem cells in early dental development is regulated by variety of transcription factors such as OCT-4, SOX-2, CD44, Nanog, Stat-3 and, c Myc ${ }^{[12]}$.

A nuclear transcription factor which is the $\mathrm{C}-\mathrm{Myc}$ protein can regulate proliferation, differentiation and, death of cells. Also, C-Myc protein can render genomic instability of cells ${ }^{[13-16]}$.

C-Myc also plays an important role in tooth development during early embryonic stages ${ }^{[17,18]}$. The expression of C-Myc is related to proliferation and differentiation of odontogenic epithelial cells ${ }^{[19]}$.
The transmembrane glycoprotein CD44 is expressed on embryonic stem cells, connective tissue cells and, cells of bone marrow ${ }^{[20]}$.

The aim of this study is to evaluate and compare the immunoexpression of two stem cell markers, which are cluster-of-differentiation-44 (CD44) and $\mathrm{C}-\mathrm{Myc}$, in dental follicles and benign epithelial odontogenic lesions.

\section{MATERIALS AND METHODS}

\section{The current study consisted of}

1- Dental follicle (DF) group: This group included 8 dental follicle specimens obtained surgically from 5 patients having impacted third molar fully covered by mucosa with no history of infection, or radiographic enlarged lesions surrounding them. Radiographic radiolucency $>$ $3 \mathrm{~mm}$ was excluded.

2- Inflammatory cyst group: It included 6 specimens of inflammatory cysts that were obtained surgically from patients with signs of inflammation related to partially impacted third molars and radicular lesions.

3- Odontogenic keratocyst group: It included 8 specimens of odontogenic keratocycst obtained surgically from posterior mandibular region

4- Dentigerous cyst group: It included 8 specimens of dentigerous cysts obtained surgically from posterior mandibular region

\section{Ethical regulations}

The complete treatment plan had been explained for all patients including detailed steps, risks, and expected results and their full signed consent was obtained prior to participating into the study. The study was performed in full accordance with the World Medical Association, Declaration of Helsinki 1975, revised in 2003 and the research ethics committee of the Faculty of Dentistry, Minia University. 


\section{Surgical procedures:}

The study samples were collected as specimens were taken when removing the dental follicle around impacted teeth indicated for extraction. Specimens from inflammatory cysts, odontogenic keratocysts and dentigerous cysts were collected at surgical intervention that included biopsy, marsupialization followed by enucleation, curettage or excision as a various treatment modalities were utilized in management of cases in the current study.

Radiographic evaluation included panoramic $\mathrm{x}$ ray, cone beam Computerized tomography (CBCT), or $\mathrm{CT}$ radiographs were obtained according to the case. In large lesions biopsies were taken in order to confirm diagnosis. All cases were operated either under local or general anesthesia according to lesion size, field access and patients conditions. The association between the follicle, pathologic lesions, age, gender and location were statistically evaluated (Table I).

\section{Histological procedures}

All specimens were immersed immediately in $10 \%$ buffered formalin. The specimens were processed to paraffin wax. Sections ( $5 \mu$ thick) were cut from each block that contains the dental follicle DF and cysts' specimens. Slides were stained with hematoxylin and eosin $(\mathrm{H} \& \mathrm{E})$ for routine histologic examination.

\section{Immunohistochemical staining}

Immunohistochemical staining (IHC) was performed using an avidin-biotin complex method ${ }^{[21]}$. For CD44 four-five $\mu \mathrm{m}$ sections were cut from paraffin-embedded tissue blocks. The tissue sections were deparaffinized and immersed in 3\% hydrogen peroxide to block endogenous peroxidase activity. The sections were washed in phosphatebuffered saline (PBS). Primary antibodies that were used are rabbit monoclonal antibody against human CD44 (1:100, Ab51037; Abcam Biotechnology Company, Cambridge, MA, USA). After treatment with normal serum, primary antibodies were used to be incubated with tissue sections in a moist chamber. These sections were washed twice in PBS and treated at room temperature with a polymer-based complex (Advance ${ }^{\mathrm{TM}}$ HRP; Dako) for anti-CD44 antibodies. Peroxidase activity was developed by immersing the tissue sections in diaminobenzidine (Liquid DAB+ Substrate; Dako), resulting in a brown reaction color. Finally, the sections were counterstained with Harris's hematoxylin, and coverslipped.

For c Myc, $4 \mu \mathrm{m}$ thickness sections of each specimen were deparaffinized then blocked with $3 \%$ peroxide. Antigens were retrieved by heating slides in a microwave oven in $50 \mathrm{mM}$ citrate buffer, $\mathrm{pH} 6.4$, at boiling temperature, for $12 \mathrm{~min}$. After blocking with 6\% normal goat serum, mouse monoclonal antibody was used to be incubated with tissue sections to human c-Myc (9E10, Sigma Chemical Company, St Louis, MO, USA) at 1:100 dilution for $2 \mathrm{~h}$, followed by $1 \mathrm{~h}$ incubation with a second antibody coupled with biotin (Vector Laboratories Inc., Burlingame, CA, USA). Finally, sections were incubated with peroxidase-conjugated avidin (Dako, Corporation, Carpinteria, CA, USA) for $30 \mathrm{~min}$, pursued by color development with diaminobenzidine and peroxide. All procedures were carried out at room temperature.

\section{Image cytometric analysis for immunohisto- chemical Evaluation}

Five microscopic fields showing the highest immunopositivity were selected and captured by a digital camera mounted on a biological research microscope at a magnification 20X. Images were then transferred to the computer system for analysis.

All the steps performed for immunohistochemical evaluation were implemented using image analysis software (Image J, 1.41a, NIH, USA). Phase analysis was calculated automatically to give the area fraction of the positive cells. The area fraction was presented by the percentage of immunopositive area to the total area of the microscopic field. 


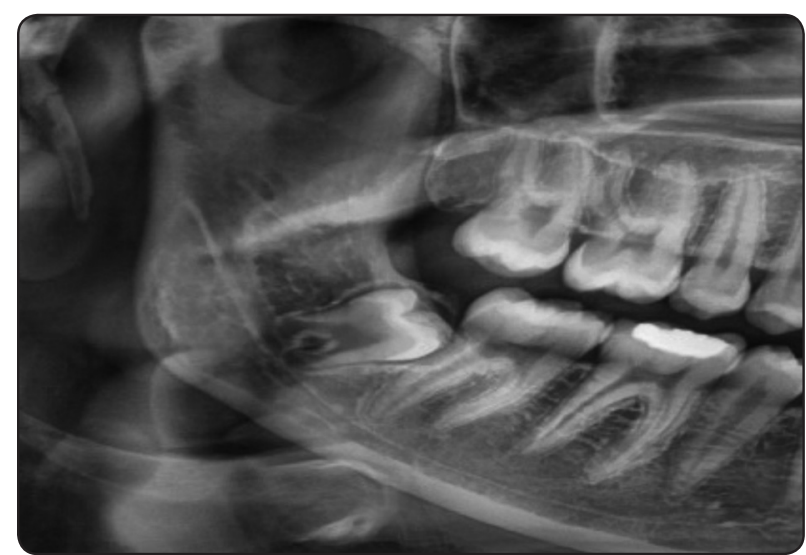

Fig. (1): Panoramic radiograph showing the follicle around impacted tooth

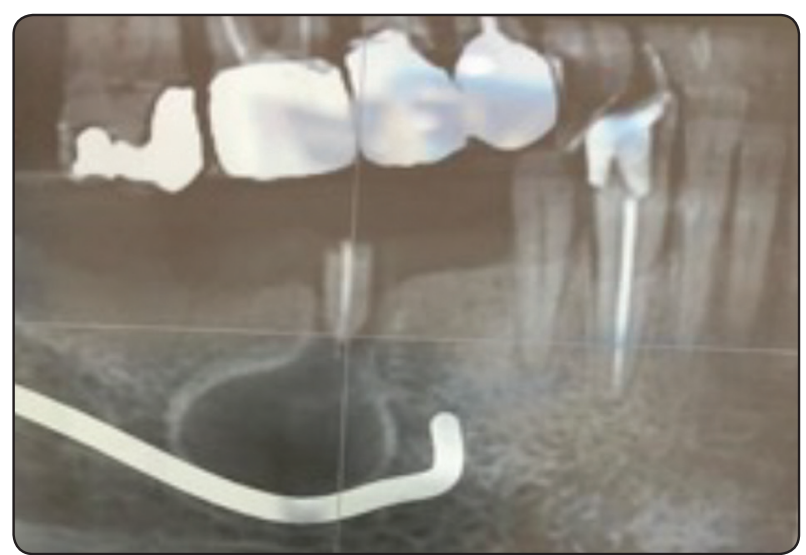

Fig. (2): Panoramic radiograph showing radicular cyst related to a remaining root

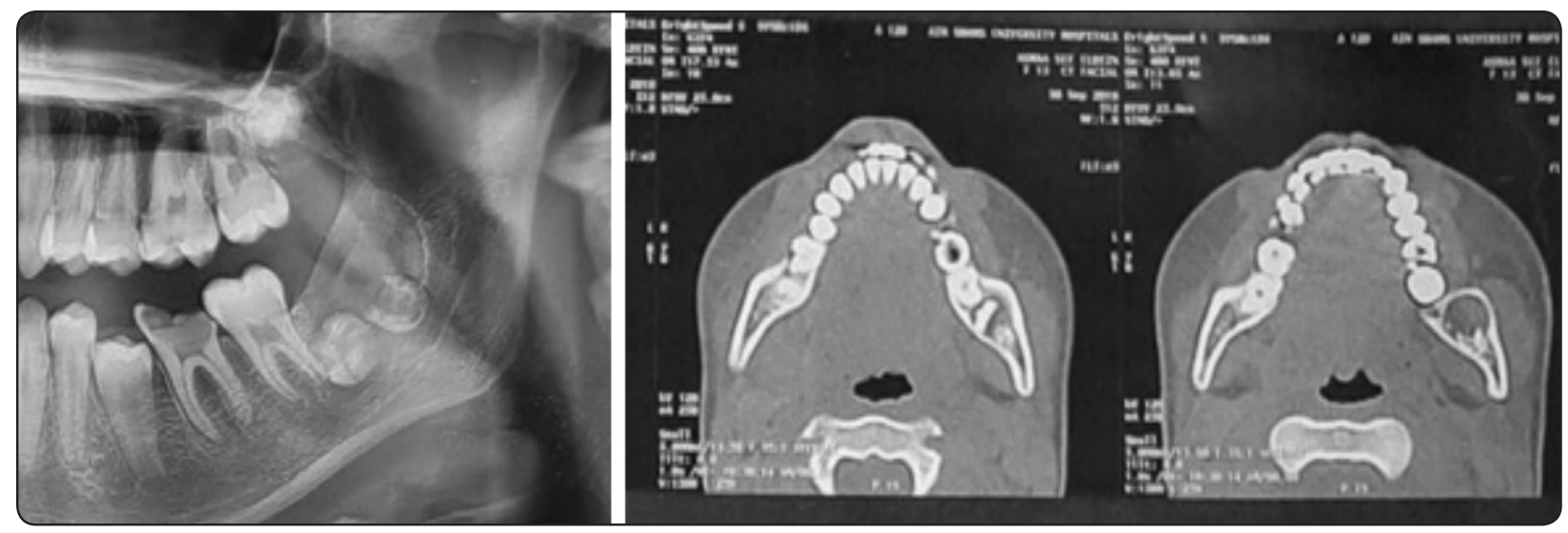

Fig. (3): Panoramic view and axial section of C.T for a dentigerous cyst

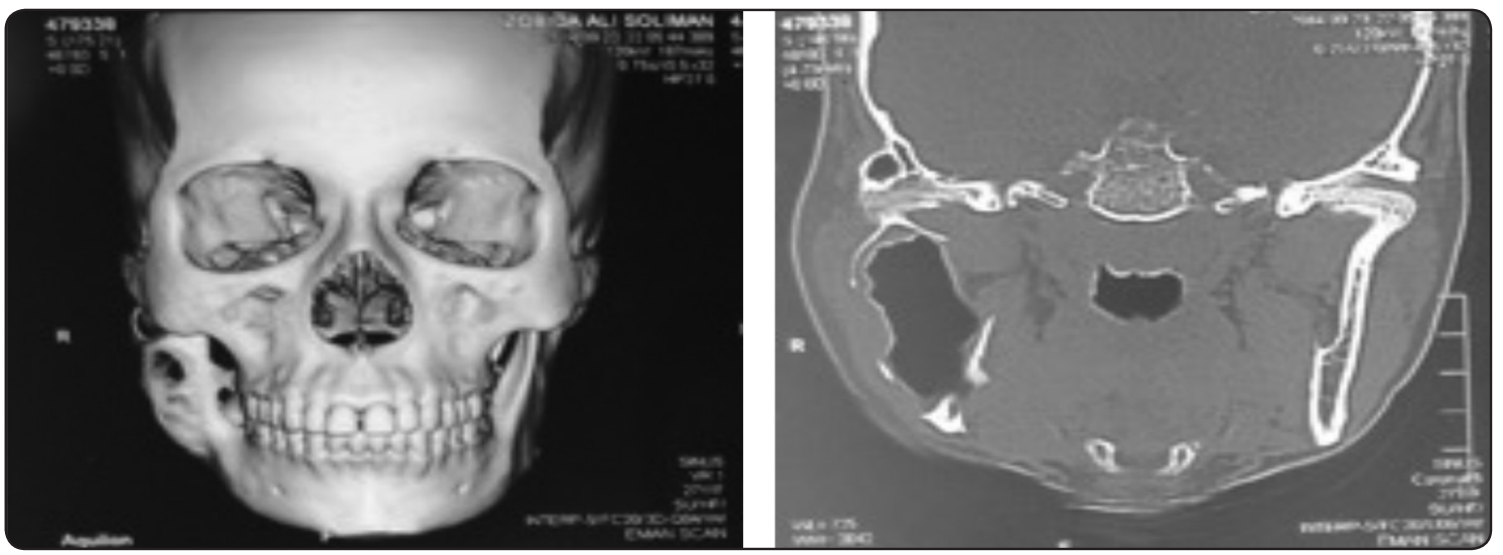

Fig. (4): C.T scan for odontogenic keratocyst lesion 
TABLE (I): Distribution of cases according to demographic characteristics:

\begin{tabular}{|c|c|c|c|}
\hline Cases & Gender & Age & Anatomic location \\
\hline $\begin{array}{l}\text { Impaction } \\
\mathrm{N}: 8\end{array}$ & $\begin{array}{l}5 \text { Females } \\
3 \text { males }\end{array}$ & $\begin{array}{l}\text { Mean: } 24.875 \\
\mathrm{SD} \pm 4.67\end{array}$ & $\begin{array}{l}6 \text { Mandibular third molars } \\
2 \text { Mandibular canines }\end{array}$ \\
\hline $\begin{array}{l}\text { Inflammatory cysts } \\
\mathrm{N}: 6\end{array}$ & $\begin{array}{l}4 \text { Females } \\
2 \text { males }\end{array}$ & $\begin{array}{l}\text { Mean:22.66 } \\
\mathrm{SD} \pm 7.23\end{array}$ & $\begin{array}{l}4 \text { posterior mandible } \\
2 \text { anterior mandible }\end{array}$ \\
\hline $\begin{array}{l}\text { Odontogenic keratocysts } \\
\text { N: } 8\end{array}$ & $\begin{array}{l}4 \text { Females } \\
4 \text { males }\end{array}$ & $\begin{array}{l}\text { Mean: } 19.75 \\
\mathrm{SD} \pm 7.47\end{array}$ & 8 posterior mandible \\
\hline $\begin{array}{l}\text { Dentigerous cysts } \\
\text { N: } 8\end{array}$ & $\begin{array}{l}4 \text { Females } \\
4 \text { males }\end{array}$ & $\begin{array}{l}\text { Mean: } 25.75 \\
\mathrm{SD} \pm 6.54\end{array}$ & $\begin{array}{l}6 \text { posterior mandible } \\
2 \text { anterior mandible }\end{array}$ \\
\hline
\end{tabular}

The collected data were tabulated using Microsoft Excel (Microsoft Office 2010). The mean area fraction for each case was deemed and used for statistical analysis.

\section{RESULTS}

Table I demonstrated the association between the follicle, pathologic lesions, age, gender and anatomical location

\section{Immunohistochemical results}

Light microscopic examination of dental follicle tissue samples stained with CD44 and c Myc revealed positive intense nuclear immunoreaction and moderate cytoplasmic immunoreaction Fig. $(5,6)$.

Regarding c Myc immunoexpression in the odontogenic lesions all cases of inflammatory cyst group showed +ve membranous staining in all layers of epithelial lining of cyst and nuclear staining in the connective tissue wall. Concerning c Myc immunoexpression in odontogenic keratocyst (OKC) group, all cases showed -ve staining in epithelial lining and connective tissue wall. In dentigerous cyst group, all cases showed +ve nuclear and membranous reaction in connective tissue wall only while epithelial lining was -ve. as shown in fig. (7-9).

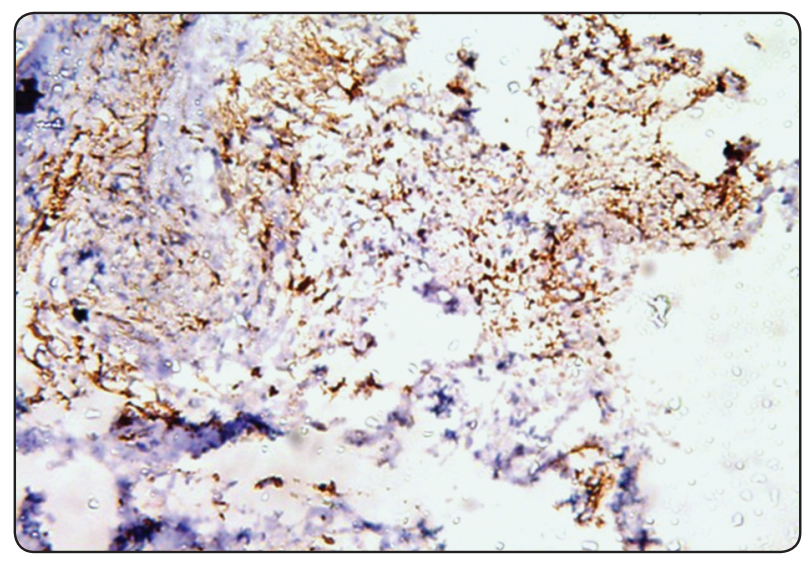

Fig. (5): photomicrograph of dental follicle of impacted third molar showing: intense nuclear immunoreaction in the stromal cells of the follicle (CD44, X 200).

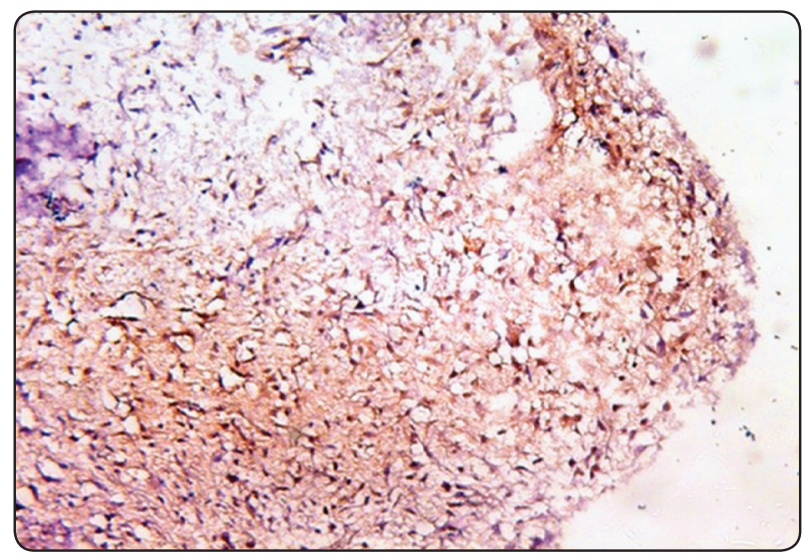

Fig. (6): photomicrograph of dental follicle of impacted third molar showing: intense nuclear and moderate cytoplasmic immunoreaction in the stromal cells of the follicle (c Myc, X 200). 


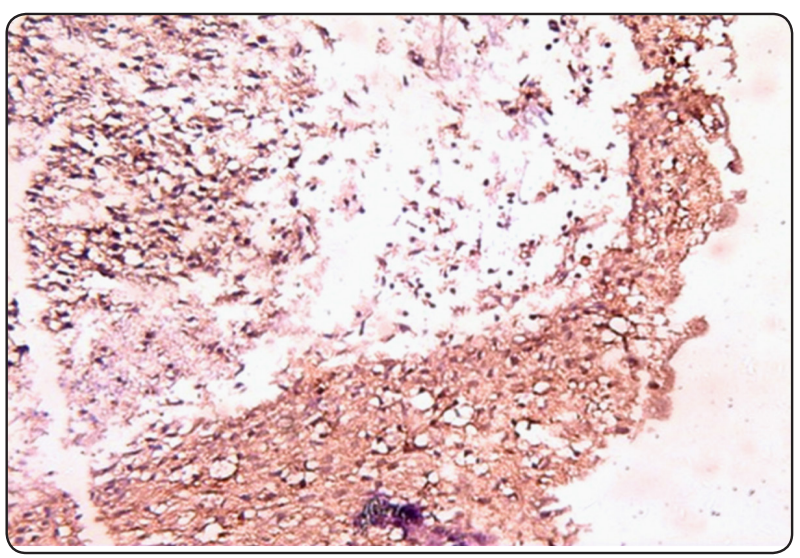

Fig. (7): photomicrograph of inflammatory cyst showing: membranous staining in all layers of epithelial lining of cyst and nuclear staining in the connective tissue wall (c Myc, X 200).

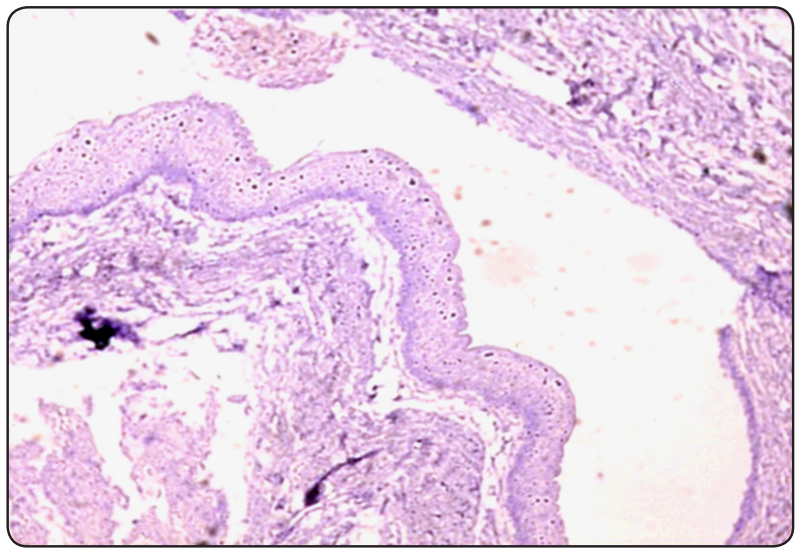

Fig. (8): photomicrograph of OKC cyst showing: -ve staining in epithelial lining and connective tissue wall (c Myc, X 200).

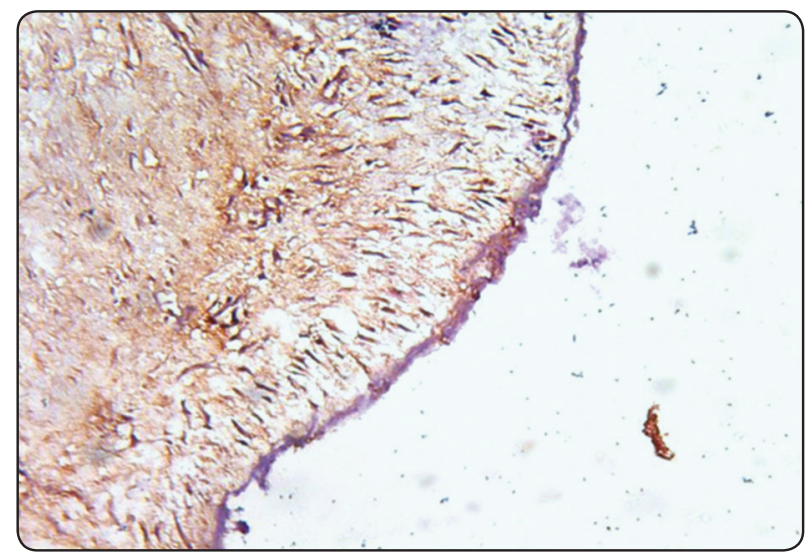

Fig. (9): photomicrograph of dentigerous cyst showing: +ve nuclear and membranous reaction in connective tissue wall only (c Myc, X 200).
Regarding CD44 immunoexpression in odontogenic lesions all cases of inflammatory cyst group showed +ve membranous staining only in basal and suprabasal layers of epithelium and nuclear staining in the connective tissue wall while in Odontogenic keratocyst group all cases sowed $+v e$ intense membranous staining in all epithelial layers except the layer of para keratin and nuclear staining in the connective tissue wall. In dentigerous cyst 4 cases (50\%) showed -ve reaction in epithelial lining and connective tissue wall and 4 cases $(50 \%)$ showed + ve nuclear reaction in connective tissue wall only as shown in fig. (10-13).

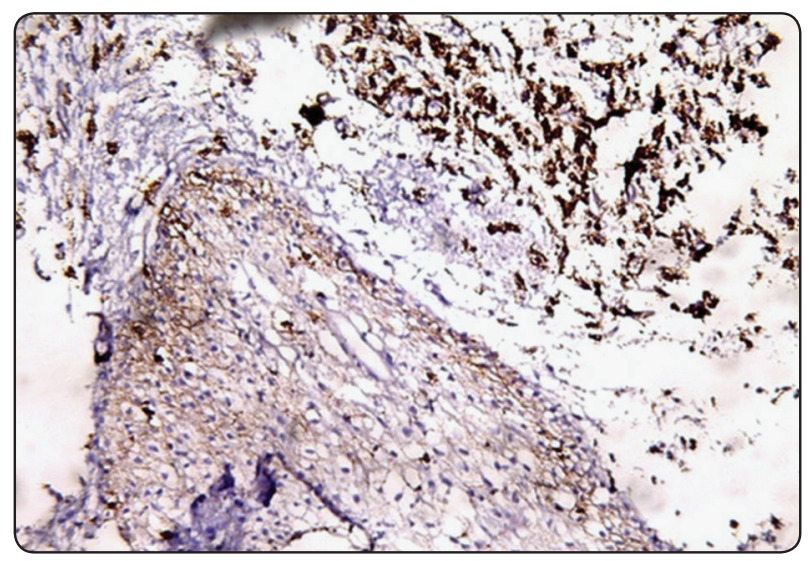

Fig. (10): photomicrograph of inflammatory cyst showing: membranous staining only in basal and suprabasal layers of epithelium and nuclear staining in the connective tissue wall (CD44, X 200).

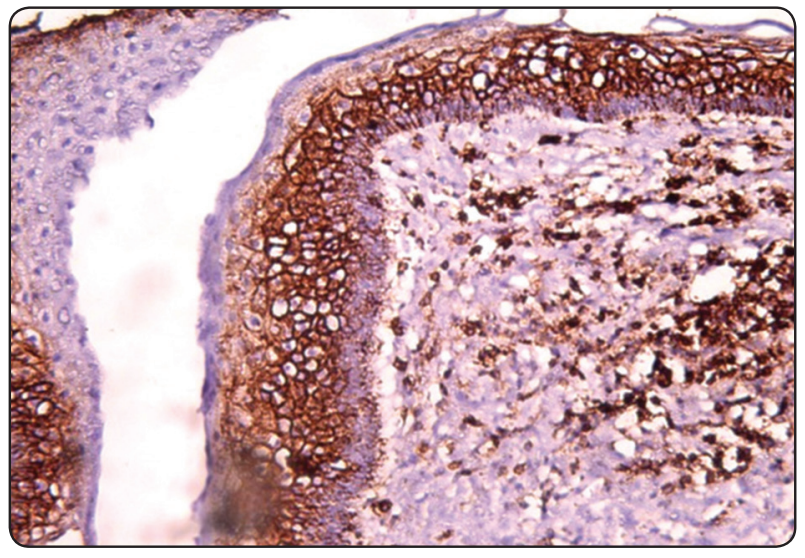

Fig. (11): photomicrograph of OKC cyst showing: +ve intense membranous staining in all epithelial layers except the layer of para keratin and nuclear staining in the connective tissue wall (CD44, X 200). 


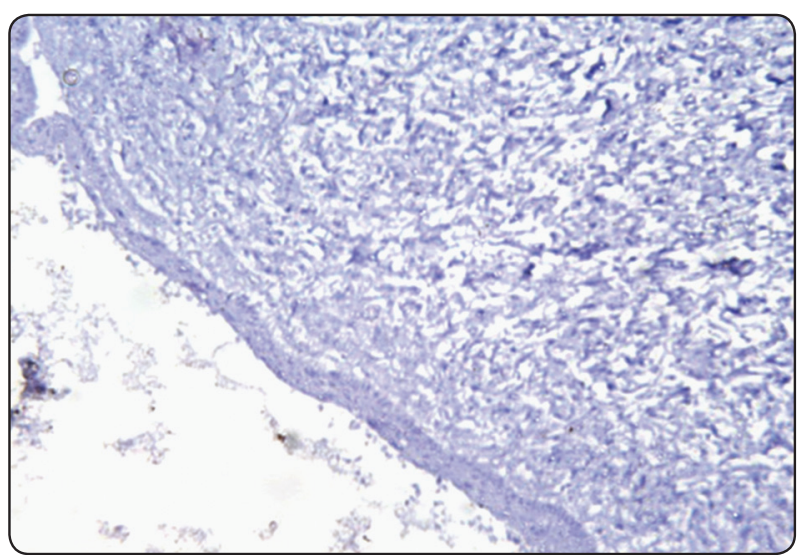

Fig. (12): photomicrograph of dentigerous cyst showing: -ve reaction in epithelial lining and connective tissue wall (CD44, X 200).

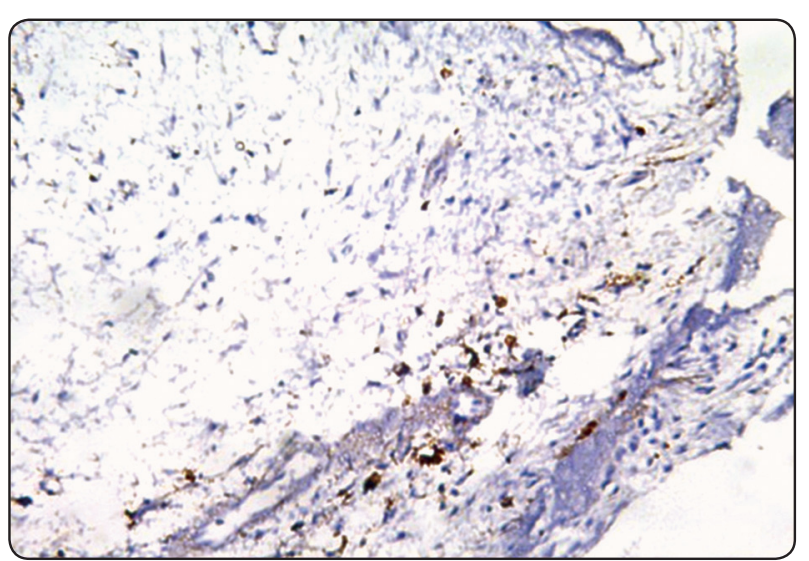

Fig. (13): Another photomicrograph of dentigerous cyst showing: +ve nuclear reaction in connective tissue wall only (CD44, X 200).

\section{Statistical results:}

Recorded data were analyzed using the statistical package for social sciences, version 20.0 (SPSS Inc., Chicago, Illinois, USA). Quantitative data were expressed as mean \pm standard deviation (SD). Comparison of numerical variables between the study groups was done using Independent-samples t-test of significance was used when comparing between two means. The confidence interval was set to $95 \%$ and the margin of error accepted was set to $5 \%$. So, the p-value was considered significant as the following: Probability (P-value) P-value $<0.05$ was considered significant.
TABLE (II): Comparison between follicle and inflammatory cysts according to CD44 and c Myc.

\begin{tabular}{|l|c|c|c|c|}
\hline & Follicle & $\begin{array}{c}\text { Inflammatory } \\
\text { cysts }\end{array}$ & t-test & p-value \\
\hline CD44 & & & & \\
Mean \pm SD & $8.55 \pm 5.80$ & $9.05 \pm 2.08$ & 0.229 & 0.822 \\
Range & $2.65-\mathrm{a} 18.35$ & $5.09-\mathrm{a} 12.29$ & & \\
\hline c Myc & & & & \\
Mean \pm SD & $5.50 \pm 2.36$ & $13.33 \pm 2.84$ & 6.001 & $<0.001 * *$ \\
Range & $2.35-\mathrm{a} 8.44$ & $9.91-\mathrm{a} 19.77$ & & \\
\hline
\end{tabular}

Using: t-Independent Sample t-test;

$P$-value $>0.05$ NS; *p-value $<0.05 \mathrm{~S} ; * *$-value $<0.001 \mathrm{HS}$

Table II shows statistically significant difference between groups according to $\mathrm{c}$ Myc.

TABLE (III): Comparison between follicle and OKC according to CD44

\begin{tabular}{|l|c|c|c|c|}
\hline & Follicle & OKC & t-test & p-value \\
\hline CD44 & & & & \\
Mean \pm SD & $8.55 \pm 5.80$ & $20.54 \pm 3.36$ & 5.059 & $<0.001 * *$ \\
Range & $2.65-\mathrm{a} 18.35$ & $18.65-\mathrm{a} 28.77$ & & \\
\hline
\end{tabular}

Using: t-Independent Sample t-test;

$P$-value $>0.05$ NS; *p-value $<0.05 S ; * * p$-value $<0.001 \mathrm{HS}$

This table shows statistically significant difference between groups according to CD44.

TABLE (IV): Comparison between follicle and dentigerous cysts according to CD44 and c Myc.

\begin{tabular}{|l|c|c|c|c|}
\hline & Follicle & $\begin{array}{c}\text { Dentigerous } \\
\text { cysts }\end{array}$ & t-test & p-value \\
\hline CD44 & $8.55 \pm 5.80$ & $1.72 \pm 1.22$ & 3.259 & $0.006^{*}$ \\
Mean \pm SD & $2.65-\mathrm{a} 18.35$ & $0.42-\mathrm{a} 3.64$ & & \\
Range & $5.50 \pm 2.36$ & $6.38 \pm 2.73$ & 0.695 & 0.499 \\
\hline c Myc & $2.35-\mathrm{a} 8.44$ & $2.53-\mathrm{a} 9.20$ & & \\
Mean \pm SD & & & \\
Range & &
\end{tabular}

Using: t-Independent Sample t-test;

$P$-value $>0.05 \mathrm{NS}$; *p-value $<0.05 \mathrm{~S}$; **p-value $<0.001 \mathrm{HS}$

This table shows statistically significant difference between groups according to CD44. 


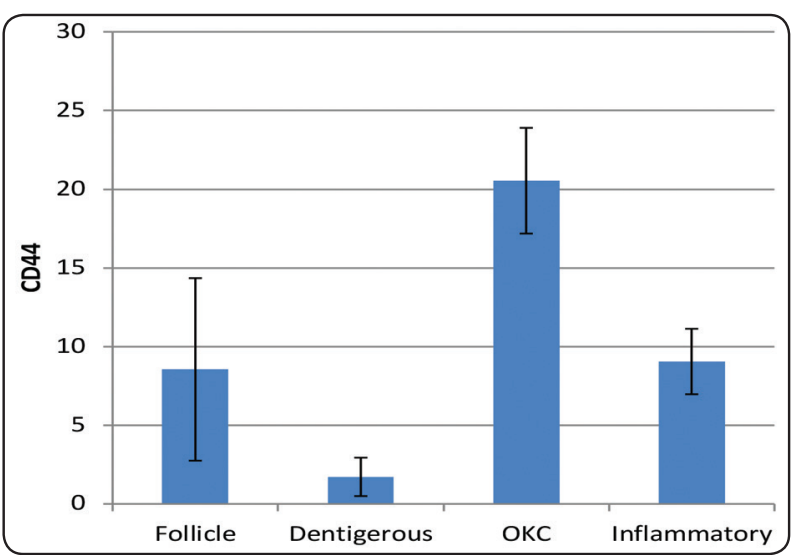

Fig. (14): Bar chart between groups according to CD44.

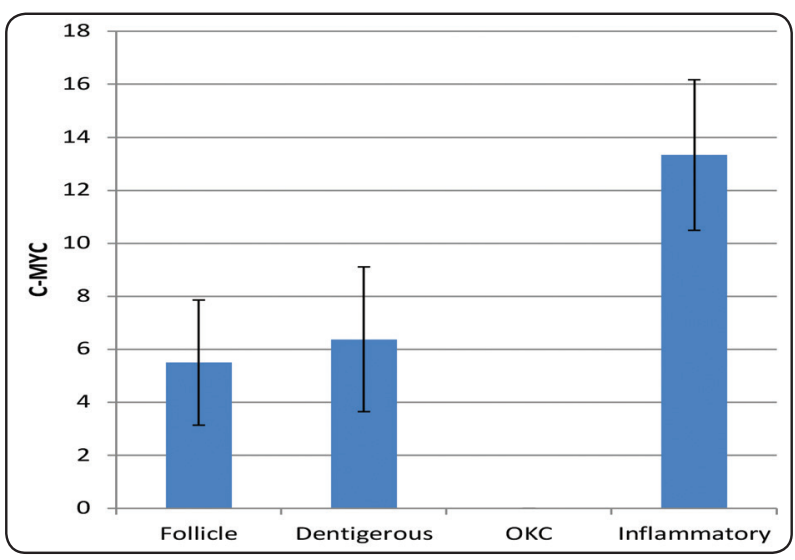

Fig. (15): Bar chart between groups according to c Myc.

\section{DISCUSSION}

The dental follicle is a fibrous connective tissue that surrounds the tooth germ. It can be isolated after third molar extraction. The follicle is an ectomesenchymal tissue composed of different cell types derived from the neural crest cells. It contains progenitor cells that differentiate during tooth development to give cementoblasts, periodontal ligament, fibroblasts and, alveolar bone osteoblasts $^{[22]}$. The dental follicle represents an interesting source of stem cells referring to the fact that it is a tissue that can be easily removed with minimum morbidity ${ }^{[23]}$.
The present study was carried out to evaluate and compare the immunoexpression of two stem cell markers, which are cluster-of-differentiation-44 (CD44) and c Myc, in dental follicles and in benign epithelial odontogenic lesions. It was suggested that any follicle with stratified squamous epithelium should be regarded as a dentigerous cyst. Cystic lesions observed in the current study were surgically removed to evaluate radicular cysts, dentigerous cysts and, odontogenic keratocyst ${ }^{[24]}$.

Tumor stem cells (TSCs) represent a small group of neoplastic cells in the tumor mass. They participate with many features with normal stem cells such as self-renewal and differentiation. Presence of TSCs represents the main factor for tumor growth as they have high tumorigenic potential. TSCs are also responsible for resistance to therapies because the cell cycle in these cells is slow as in normal stem cells ${ }^{[25]}$.

Results revealed positive intense nuclear immunoreaction and moderate cytoplasmic immunoreaction in the mesenchymal cells of the follicle.

These results were supported with other findings reported in the dental follicles from human wisdom teeth. Authors investigated the presence of stem cells in the follicles using immunohistochemical staining and found that all tissue samples showed positive immunoreaction for CD44 ${ }^{[26]}$. In addition, it was reported that dental follicle stem cells expressed CD44 ${ }^{[6]}$. Regarding C-Myc immunoexpression in dental follicle cells, positive nuclear and cytoplasmic immunoexpression of $\mathrm{c}$ Myc in dental follicle cells were detected by other study carried by Karamzadeh and coworkers confirming our results ${ }^{[27]}$.

Concerning c -Myc immunoexpression in the odontogenic lesions, results of the present study revealed +ve membranous staining in all layers of epithelial lining of inflammatory cyst and nuclear staining in the connective tissue wall. In Odontogenic keratocyst (OKC) group, all cases showed -ve staining in epithelial lining and connective tissue 
wall. In concern to dentigerous cyst group, all cases showed +ve nuclear and membranous reaction in connective tissue wall only.

It was said that human periapical inflammatory tissues expressed mesenchymal stem cell (MSC) markers, suggesting the presence of MSCs ${ }^{[28]}$.

It was also demonstrated that MSCs that are isolated from pathological dental tissues possess many similarities with MSCs that are isolated from healthy tissues. ${ }^{[29]}$.

The immunoex pression of c-Myc in inflammatory cyst was higher than that in dentigerous cyst. In relation to the dental follicle there was statistically significant difference $<0.001 * *$ between follicle and inflammatory cyst.

These results were also parallel and backed up by other research that recorded $50 \%$ positivity for c Myc expression in radicular cyst and $20 \%$ positivity in dentigerous cyst ${ }^{[19]}$. On the other hand, results of the present study were in contrast to that found by Moosvi and coworkers who detected $80 \%$ positivity for c-Myc expression in OKC ${ }^{[19]}$.

Our findings regarding CD44 immunoexpression in odontogenic lesions revealed that all cases of inflammatory cyst group showed +ve membranous staining only in basal and suprabasal layers of epithelium and nuclear staining in the connective tissue wall. In Odontogenic keratocyst group all cases showed +ve intense membranous staining in all epithelial layers except the layer of para keratin and nuclear staining in the connective tissue wall. The 4 cases of dentigerous cyst ( $50 \%$ of cases) showed -ve reaction in epithelial lining and connective tissue wall and the other 4 cases $(50 \%)$ showed +ve nuclear reaction in connective tissue wall only.

Variable membrane positivity in the epithelial cells of all OKCs was found in another study upholding our findings ${ }^{[30]}$.

The immunoexpression of CD44 in OKC was much higher than the expression in inflammatory and dentigerous cysts. And in relation to dental follicle there was statistically significant difference between follicle and $\mathrm{OKC}<0.001 * *$ and also statistically significant difference between follicle and dentigerous cyst $0.006^{*}$.

These results were in agreement with Wang and his coworkers who reported that the expression of CD44 in the previous studies in odontogenic lesions showed high and diffuse expression in the epithelium of $\mathrm{OKC}^{[30]}$. In addition, it was said that cells which express stem cell markers, such as CD44, were also positive for $\mathrm{Ki}-67$ which is a marker of proliferation [31].

Depending on the proliferative capacity of stem cells, the higher expression of CD44 present in the OKCs might be related to the high proliferation activity of this lesion.

Investigators found positive reaction to OCT4 and SOX2 which are epithelial stem cell (ESC) markers in odontogenic lesions as cases of follicular tissue, dentigerous cyst, and radicular cyst [32]. These findings are in agreement with our results

\section{CONCLUSION}

Results of the present study depict the presence of stem cells in dental follicle and in benign odontogenic lesions and clarify their role in the pathogenesis of these odontogenic lesions.

\section{REFERENCES}

1. Banerjee A, et al. OCT4 and SOX2 are reliable markers in detecting stem cells in odontogenic lesions. Journal of Orofacial Sciences, 2016. 8(1): p. 16-21.

2. Bilodeau EA. and BM. Collins, Odontogenic cysts and neoplasms. Surgical pathology clinics, 2017. 10(1): p. 177-222.

3. Mamabolo MC. Noffke and E. Raubenheimer. Odontogenic tumours manifesting in the first two decades of life in a rural African population sample: a 26 year retrospective analysis. Dentomaxillofacial Radiology, 2011. 40(6): p. 331-337.

4. Chang JYF. et al. Self-renewal and multilineage differentiation of mouse dental epithelial stem cells. Stem cell research, 2013. 11(3): p. 990-1002. 
5. Yao S, et al. Differentiation of Stem Cells in the Dental Follicle. Journal of Dental Research, 2008. 87(8): p. 767-771.

6. Rodríguez-Lozano FJ, et al., Mesenchymal stem cells derived from dental tissues. International Endodontic Journal, 2011. 44(9): p. 800-806.

7. Satheesan E, et al. Histopathological and Radiographic Analysis of Dental Follicle of Impacted Teeth Using Modified Gallego's Stain. Journal of clinical and diagnostic research : JCDR, 2016. 10(5): p. ZC106-ZC111.

8. Godoy GP, et al. Immunohistochemical profile of integrins in enlarged dental follicles and dentigerous cysts. Oral Surgery, Oral Medicine, Oral Pathology, Oral Radiology, and Endodontology, 2007. 104(6): p. e29-e34.

9. Slater LJ. DENTIGEROUS CYST VERSUS DENTAL FOLLICLE. British Journal of Oral and Maxillofacial Surgery, 2000. 38(4): p. 402.

10. Harada $\mathrm{H}$, et al. Epithelial stem cells in teeth. Odontology, 2002. 90(1): p. 0001-0006.

11. Islam F, et al. Cancer stem cell: fundamental experimental pathological concepts and updates. Experimental and molecular pathology, 2015. 98(2): p. 184-191.

12. Ramanathan A, et al. Homeobox genes and tooth development: Understanding the biological pathways and applications in regenerative dental science. Archives of oral biology, 2018. 85: p. 23-39.

13. Dang CV. c-Myc target genes involved in cell growth, apoptosis, and metabolism. Molecular and cellular biology, 1999. 19(1): p. 1-11.

14. Persson H. and P. Leder.Nuclear localization and DNA binding properties of a protein expressed by human c-myc oncogene. Science, 1984. 225(4663): p. 718-21.

15. Studzinski GP, et al. Participation of c-myc protein in DNA synthesis of human cells. Science, 1986. 234(4775): p. 467-70.

16. Evan GI, et al. Induction of apoptosis in fibroblasts by cmyc protein. Cell, 1992.69(1): p. 119-28.

17. Pfeifer-Ohlsson S, et al. Cell-type-specific pattern of myc protooncogene expression in developing human embryos. Proc Natl Acad Sci U S A, 1985. 82(15): p. 5050-4.

18. Schmid P, WA. Schulz and H, Hameister. Dynamic expression pattern of the myc protooncogene in midgestation mouse embryos. Science, 1989. 243(4888): p. 226-9.

19. Moosvi Z, and K, Rekha. c-Myc oncogene expression in selected odontogenic cysts and tumors: An immunohisto- chemical study. Journal of oral and maxillofacial pathology : JOMFP, 2013. 17(1): p. 51-56.

20. Gronthos S, et al. Surface protein characterization of human adipose tissue-derived stromal cells. J Cell Physiol, 2001. 189(1): p. 54-63.

21. Liao DZ, et al. Promotion of estrogen-induced mammary gland carcinogenesis by androgen in the male Noble rat: probable mediation by steroid receptors. Carcinogenesis, 1998. 19(12): p. 2173-2180.

22. A R,Ten Cate AR. Oral histology: development, structure, and function. 6th ed. 2003.

23. Kémoun P, et al. Human dental follicle cells acquire cementoblast features under stimulation by BMP-2/-7 and enamel matrix derivatives (EMD) in vitro. Cell and Tissue Research, 2007. 329(2): p. 283-294.

24. Dongol A, et al. Dentigerous Cystic Changes in the Follicles Associated with Radiographically Normal Impacted Mandibular Third Molars. International Journal of Dentistry, 2018. 2018: p. 2645878.

25. Almeida LO, et al. Profiling the behavior of distinct populations of head and neck cancer stem cells. Cancers, 2016. 8(1): p. 7.

26. Angiero F, et al. Stromal phenotype of dental follicle stem cells. Front Biosci (Elite Ed), 2012. 4: p. 1009-14.

27. Karamzadeh R, M. Baghaban Eslaminejad and A, SharifiZarchi. Comparative In Vitro Evaluation of Human Dental Pulp and Follicle Stem Cell Commitment. Cell journal, 2017. 18(4): p. 609-618.

28. Liao J, et al. Cells isolated from inflamed periapical tissue express mesenchymal stem cell markers and are highly osteogenic. Journal of endodontics, 2011.37(9): p. 1217-1224.

29. Park JC, et al. Isolation and characterization of human periodontal ligament (PDL) stem cells (PDLSCs) from the inflamed PDL tissue: in vitro and in vivo evaluations. Journal of clinical periodontology, 2011.38(8): p. 721-731.

30. Wang Y-P, and B-Y, Liu. High expression of osteopontin and CD44v6 in odontogenic keratocysts. Journal of the Formosan Medical Association, 2009. 108(4): p. 286-292.

31. Sathi GA, et al. Analysis of immunoexpression of common cancer stem cell markers in ameloblastoma. Experimental and Therapeutic Medicine, 2012.3(3): p. 397-402.

32. Yan X, et al. iPS cells reprogrammed from human mesenchymal-like stem/progenitor cells of dental tissue origin. Stem Cells Dev, 2010. 19(4): p. 469-80. 